Volume 3, Issue 4 October-December 2018, Pages: 273, DOI: http://dx.doi.org/10.19082/ah273

\title{
STUDY OF ANTIBACTERIAL ACTIVITY OF PISTACIA LENTISCUS ESSENTIAL OIL
}

\author{
DRIS Ibrahim ${ }^{1}$, BEKADA Ahmed Mohamed Ali ${ }^{1}$, ATTALA Nabila², AIT SAADA Djamel ${ }^{1}$
}

drisibrahime@gmail.com

1: Laboratory of Biology of Plants, University Abdelhamid IbnBadis of Mostaganem, Algeria

2: Laboratory of Pharmacognosis ApiPhytotherapy, University AbdelhamidI bnBadis of Mostaganem, Algeria

\section{TYPE OF ARTICLE: CONFERENCE ABSTRACT}

\begin{abstract}
The botanic genre Pistacia is a group of around fifteen species of shrubs that belong to the Anacardiaceae family native to Asia and the Mediterranean. Pistacia lentiscus is an abundant species of the Pistacia genre encountered in the forest region of the Ouarsenis mountain range (Northwest of Algeria), specifically the national park of Theniet El Had in the Wilaya de Tissemsilt. The species' essential oils could be explored to test their antimicrobial activity, especially against particular bacteria that cause alimentary intoxications. The study was carried out in the Laboratory of Plant Biology at Abdelhamid Ibn Badis University in Mostaganem, Algeria, during 2017. The aim of the current study was to evaluate the anti-bacterial activity of the essential oil of Pistacia lentiscus against pathogen bacteria using the disk diffusion methods. The antibiogram is made following the gliosisenvironment diffusion method, and makes it possible to determine the bacteria's sensibility to antibiotics. From a young culture (18 to 24 hours), a bacterial suspension is prepared and well homogenized afterward. The opacity must be equivalent to $0.5 \mathrm{McF}$ (McFarland), the O.D being between 0.08 and 0.1 read at $625 \mathrm{~nm}$. The results revealed that the essential oil exhibited strong levels of antibacterial activity against the tested microorganism regarding the MIC values. Salmonella had a great sensitivity to the essential oil. The biggest inhibition zones have been obtained for Salmonella sp, Acinetobacter sp. Staphylococcus aureus and Bacillus sp (23, 20, 19 and $19 \mathrm{~mm}$, respectively). So, we considered that those microorganisms were more sensitive to that oil. In the same way, Pseudomonas aeruginosa has been judged to be more sensitive to the oil than prot (16 and $12 \mathrm{~mm}$, respectively). Based on the findings of the present study, novel antibacterial agents could be developed, and it is recommended that the use of Pistacia lentiscus be promoted in traditional treatment.

KEYWORDS: Pistacia lentiscus, Essential oils, Antimicrobial power, Pathogen bacteria
\end{abstract}

\footnotetext{
Abstracts of Third International Conference on Health Sciences and Medical Technologies, October 2018, Tlemcen, Algeria (ICHSMT-18)

(C) 2018 The Authors. This is an open access article under the terms of the Creative Commons Attribution-NonCommercialNoDerivs License, which permits use and distribution in any medium, provided the original work is properly cited, the use is non-commercial and no modifications or adaptations are made.
} 